\title{
The surgeon's perspective: a retrospective study of wide local excisions taken to healthy subcutaneous fat in the management of advanced hidradenitis suppurativa
}

\author{
Eran Shavit, MD \\ Andrew Pawliwec, MBBS, MSc \\ Afsaneh Alavi, MD, MSc \\ Ralph George, MD
}

Accepted July 15, 2019

\author{
Correspondence to: \\ E. Shavit \\ Department of Medicine \\ Women's College Hospital, 5 South \\ 76 Grenville St \\ Toronto ON M5S 1B2 \\ erans29@gmail.com
}

DOI: $10.1503 /$ cjs.003119
Background: Hidradenitis suppurativa (HS) is a chronic debilitating folliculopilosebaceous disease that affects the skin most commonly in the axilla, groin, inframammary, genital and buttock areas. Surgical intervention may be an appropriate option in selected cases, but there is a risk of recurrence. The purpose of this study was to assess the results of wide local excision (WLE) to healthy subcutaneous fat with secondary intention healing in patients with HS who were under concurrent surgical and dermatologic care.

Methods: We conducted a retrospective review of 192 consecutive HS consultations to a general surgical service, identifying patients treated with WLE. Cases involving minor procedures (deroofing, incision and drainage) were excluded. Data on patient demographics, surgical site, method of closure, complications and recurrence were extracted from patient charts. We also conducted a literature review of surgical procedures in the management of HS.

Results: A total of 66 patients underwent 133 WLE to healthy subcutaneous fat. All patients were under concurrent medical care directed by a dermatologist. No medical therapies, including biological treatments, were interrupted or withheld for surgery. One hundred procedures were closed primarily with rotation or advancement flaps and 33 by secondary intention healing. Local recurrence occurred in $18 \%$ of primary closures and $18 \%$ of secondary intention closures $\left(p=0.98, \chi^{2}\right.$ test, no difference between groups). One patient with secondary intention healing returned to the emergency department for bleeding; $34 \%$ of patients with primary closure experienced some dehiscence (23\% major, $11 \%$ minor separation). Two patients with axillary disease had restrictions in their ability to raise their arm that required physiotherapy. Median follow-up was 14.5 (range 1-55) months.

Conclusion: Resection to healthy subcutaneous fat during WLE provides disease control comparable to that with deeper resections, simplifying care.

Contexte : L'hidradénite suppurée (HS) est une maladie invalidante chronique du follicule pilo-sébacé qui affecte la peau principalement au niveau de l'aisselle, de l'aine, du pli sous-mammaire et du siège. Une intervention chirurgicale pourrait être une option appropriée dans certains cas, mais il y a un risque de récurrence. Le but de cette étude était d'évaluer les résultats d'une excision locale large (ELL) jusqu'aux tissus adipeux sous-cutanés sains suivie de cicatrisation secondaire chez des patients atteints d'HS recevant concomitamment des soins chirurgicaux et dermatologiques.

Méthodes : Nous avons procédé à une revue rétrospective de 192 consultations consécutives pour HS dans un service de chirurgie générale et nous avons recensé les patients traités par ELL. Les cas impliquant des interventions mineures (par incisiondrainage) ont été exclus. Les données démographiques, le site chirurgical, la méthode de suture, les complications et les récurrences ont été enregistrés à partir des dossiers des patients. Nous avons aussi procédé à une revue de la littérature sur les interventions chirurgicales pour l'HS.

Résultats : En tout, 66 patients ont subi 133 interventions d'ELL jusqu'aux tissus adipeux sous-cutanés sains. Tous les patients prenaient concomitamment un traitement médicamenteux sous la supervision d'un dermatologue. Aucun des traitements médicamenteux, y compris les agents biologiques, n'a été suspendu ou interrompu pour la chirurgie. Cent interventions ont été refermées principalement par lambeaux de rotation ou d'avancement et 33 par cicatrisation secondaire. Les récurrences 
locales ont affecté $18 \%$ des fermetures primaires et $18 \%$ des fermetures par cicatrisation secondaire ( $p=0,98$, test du $\chi^{2}$, aucune différence entre les groupes). Un patient soumis à la cicatrisation secondaire est retourné aux urgences pour un saignement; $34 \%$ des patients ayant subi une fermeture primaire ont présenté un certain degré de déhiscence (23\% majeure, $11 \%$ mineure). Deux patients ayant une atteinte axillaire ont connu des restrictions dans leur capacité de lever les bras et ont dû faire de la physiothérapie. Le suivi médian a été de 14,5 (éventail de 1 à 55) mois.

Conclusion : La résection jusqu'aux tissus adipeux sous-cutanés sains durant l'ELL permet de maîtriser la maladie aussi bien que les résections plus profondes, mais simplifie les soins.

H idradenitis suppurativa (HS) is a chronic disease affecting the folliculopilosebaceous unit. ${ }^{1}$ The disease was roughly divided into 3 surgical stages by Hurley, but newer staging systems have been described and apply to the evaluation of medical therapies. ${ }^{2-4}$ In its severe forms the disease is a painful, malodorous, socially isolating condition that profoundly affects patients' lives. It typically begins in adolescence or early adulthood. The condition can be exacerbated by obesity and smoking but is not caused by either. ${ }^{3,5}$ It is characterized by recurrent inflammatory nodules in characteristic areas, but repeated episodes can create heaped scars and chronic sinuses or tunnels under the skin surface.

As an inflammatory disease HS is managed collaboratively with medical and surgical approaches. ${ }^{6}$ Modern evidence-based guidelines address medical care, and surgery can play an important role in both localized and more severe disease. ${ }^{7}$ The choice of surgical intervention will depend on presentation. The most common procedure is incision and drainage, performed in the acute setting, such as in emergency departments. Other common procedures include deroofing, steroid injections and limited local excisions, which are typically done as office procedures. Wide local excision (WLE) is another technique in which excision extends beyond the margins of the gross disease and into the subcutaneous layer. It is often done for extensive axillary or groin involvement and can be closed by flaps, grafts or secondary intention healing. However, previous reports have suggested high recurrence rates, between $27 \%$ and $100 \%$ depending on the procedures performed. ${ }^{8-12}$ In recent years, a growing number of reports of surgical interventions for patients with HS have shown more promising results. ${ }^{13}$ Even in the setting of local recurrence postoperatively, the disease is usually more manageable and less extensive than preoperatively.

The purpose of this study was to assess the results of WLE with secondary intention healing to healthy subcutaneous fat in patients with HS who were under concurrent surgical and dermatologic care. We focused on WLE specifically to healthy adipose tissue rather than fascia, similar to full-thickness laser ablations, which have been found to produce good results. ${ }^{14-16}$ This technique is based on the understanding that HS has a pilosebaceous origin rather than an apocrine gland source. A shallower excision simplifies the procedure and can eliminate the need for complex reconstruction in many cases. This technique also expands the opportunities for secondary intention healing as a closure option.

\section{Methods}

A retrospective chart review of 192 consecutive HS consultations to a general surgical service at St. Michael's Hospital in Toronto, Canada, was undertaken to identify patients treated with WLE. Patients who underwent minor procedures (deroofing, incision and drainage) were excluded. Data on patient demographics, surgical site, method of closure, complications and recurrence rate were extracted from patient charts.

This study was approved by the Unity Health Toronto Research Ethics Board of St. Michael's Hospital, University of Toronto.

We also conducted a literature review of surgical approaches to the management of HS. We included only traditional surgical techniques (laser surgery and any other techniques using energy-based devices were excluded). We searched PubMed and EMBASE between 2000 and the end of June 2018 using the following terms: "hidradenitis suppurativa," "acne inversa" and "surgery." The literature search was limited to articles published in English.

\section{RESULtS}

Sixty-six patients underwent 134 WLE. The median age of the patients was 37 years (range 18-61 yr). The sites of surgery were the axilla (44 procedures), the inguinal region (40 procedures), the breast and inframammary region (13 procedures), the genitals (vulva, mons, scrotum, 18 procedures), the posterior neck ( 2 procedures) and the buttocks, perianal and natal cleft areas (17 procedures). All WLE were extended to healthy subcutaneous fat. In all cases we removed gross disease including draining sinuses, obvious nodules and heaped scarring. While performing procedures we were attentive to any tracks or tunnels emanating from the more obvious disease. Our goal was to resect to healthy tissue radially as well as to healthy subcutaneous tissue in terms of depth.

One hundred procedures were closed primarily with rotation or advancement flaps and 34 were closed by secondary intention healing. Local recurrence was defined 
as disease appearing within $0.5 \mathrm{~cm}$ of the resection site; this definition was based on a previous study. ${ }^{13}$ There was local recurrence in $18 \%$ of cases (18 of 100$)$ with primary closures and in $18 \%$ of cases ( 6 of 33 ) in which the wound healed by secondary intention $\left(p=0.98, \chi^{2}\right.$ test, no statistically significant difference between groups). One patient with secondary intention healing returned to the emergency department for bleeding, which was controlled with silver nitrate; $34 \%$ of patients with primary closure experienced some dehiscence (23\% experienced major dehiscence requiring nursing and home care, $11 \%$ experienced minor separation). Two patients with axillary disease who underwent primary closure experienced restrictions in their ability to raise their arm that required physiotherapy.

All patients had ongoing dermatology follow-up. Ninety-four percent of patients were taking medication at the time of surgery; we did not discontinue any therapies for the surgery. Fifty-one percent of patients were on oral antibiotics (usually clindamycin/rifampin or doxycycline), $29 \%$ were on biologic therapy (anti-tumour necrosis factor $\alpha$ ) combined with oral antibiotics, $8 \%$ were on biologic therapy combined with intravenous antibiotics (ertapenem) and 6\% were on biologic therapy alone. Patients were treated to what we felt was maximal medical benefit, and surgery focused on persistent areas of disease, drainage and flaring.

The median duration of follow-up was 14.5 months (range 1-55 mo). All patients were followed concurrently by dermatologic and surgical services. No patients were lost to follow-up.

Our initial literature search produced 255 articles. When we narrowed the search with the term "wide local excision," we found 30 publications, 8 of which were review articles. Table 1 provides a summary of the 22 articles that remained after we excluded the review articles, including data on patient demographics, type of surgical procedure, location of surgery and recurrence rate.

\section{Discussion}

Hidradenitis suppurativa is a chronic, debilitating disease that leads to clinically scarred areas in affected anatomic regions, such as the axilla and genitals, leading to tremendous disability, low self-esteem and substantially reduced body image. ${ }^{17}$ The tunnels and ropelike scars in HS may also be a place for growing biofilms as a potential trigger for the recurrence of inflammation in these areas. Almost $70 \%$ of chronic lesions were shown to present with biofilms, based on recent studies. ${ }^{18}$ Surgical intervention is important for removal of these tunnels and scars. Concerns have been raised previously about the high recurrence rate. ${ }^{19-21}$ Much of the surgical literature from 1997 to 2017 recommends extending excisions for HS to the muscular fascia, removing apocrine gland projections into the subcutaneous layer; these studies have reported recur- rence rates of $3 \%$ to $54 \% .{ }^{19-22}$ In 2018 , Walter and colleagues reported a postoperative recurrence rate as high as $54.2 \% .^{22}$ In contrast, Deckers and colleagues reported a $38 \%$ recurrence rate when WLE was used..$^{13}$ Recurrence was defined in their study as a new inflammatory nodule within $0.5 \mathrm{~cm}$ of the lesion. ${ }^{13,23}$

Our recurrence rate was $18 \%$ for primary closures and $18 \%$ for secondary intention closures, and the study included only patients for whom excision was performed to healthy subcutaneous adipose tissue. No patient underwent resection to muscular fascia. The rationale for this approach is the newer understanding of HS as a pilosebaceous unit disease rather than a disease of the sweat glands, meaning that resection does not need to go to fascia but rather simply to healthy tissue. This simplifies the surgery and makes closures less complicated. When compared with the results of earlier studies, our results were not superior, but rather were equivalent to more aggressive approaches. Our results are promising, suggesting equivalent or better local control than most series, despite the purposeful effort to limit the depth of tissue removed. Interestingly, only 2 $(3 \%)$ of our patients with axillary disease experienced restrictions in their ability to raise their arm that required physiotherapy.

As mentioned earlier, all of our patients were under medical care. Many were receiving combinations of medical care to achieve as much medical control over their inflammation as possible. Surgery (WLE) was reserved for areas of persistent drainage and flaring that had not responded to medical treatment.

The decision whether to close wounds with flaps or with secondary intention healing was made case by case, with patients' input and preferences taken into consideration. Patients were shown photos of previous cases that involved secondary intention closure so that they would know what to expect. Their preference was to use secondary intention closure for larger defects. In our study, $43 \%$ of axillary wounds, $13 \%$ of inguinal wounds, $23 \%$ of genital wounds and $41 \%$ of buttock (including perianal, natal cleft) wounds were closed by secondary intention healing. The choice not to use skin grafts is not evidence-based but it reflects our experience. There are a few advantages of secondary intention closure over skin grafting, including the following: the use of a donor site is avoided, no immobilization is required (difficult areas are the axilla and the inguinal regions), the patient is able to move and use the extremity for maximum range of motion as the wound heals, and it is an easier surgical approach.

This series leaves us preferring secondary intention over primary intention closure for many cases. Secondary intention closure seems advantageous for wider areas of excision. It enables us to avoid skin grafting and complex flaps with disease control that is equivalent to that of more involved surgical approaches. Secondary intention closure provided for good range of motion with good cosmesis 
Table 1 (part 1 of 2). Summary of articles on surgical interventions in patients with hydratenitis suppuritiva published since 2000

\begin{tabular}{|c|c|c|c|c|c|c|c|}
\hline Study and country & $\begin{array}{l}\text { No. of } \\
\text { patients }\end{array}$ & Study design & Sex & Age, yr & Location of surgery (\%) & Type(s) of procedure(s) & $\begin{array}{l}\text { Recurrence } \\
\text { rate, \% }\end{array}$ \\
\hline $\begin{array}{l}\text { Walter et al. }{ }^{22} 2018 \\
\text { Germany }\end{array}$ & 48 & $\begin{array}{l}\text { Single centre, } \\
\text { retrospective }\end{array}$ & & & & WLE & 54.2 \\
\hline $\begin{array}{l}\text { Deckers et al. }{ }^{13} \\
2018 \\
\text { The Netherlands }\end{array}$ & 84 & $\begin{array}{l}\text { Single centre, } \\
\text { retrospective }\end{array}$ & $\begin{array}{c}48 \text { men }(57.1 \%) \text {, } \\
36 \text { women } \\
(42.9 \%)\end{array}$ & & $\begin{array}{l}\text { Axillary }(22.1) \text {, inguinal/ } \\
\text { femoral }(37.2) \text {, genital } \\
\text { (12.3), gluteal/anal (25), } \\
\text { other (2.8) }\end{array}$ & $\begin{array}{l}\text { WLE with } \\
\text { secondary intention closure }\end{array}$ & 38 \\
\hline $\begin{array}{l}\text { Kofler et al. }{ }^{25} 2018 \\
\text { Germany }\end{array}$ & 255 & $\begin{array}{l}\text { Retrospective, } \\
\text { questionnaires }\end{array}$ & $\begin{array}{l}103 \text { men, } \\
152 \text { women, }\end{array}$ & $\begin{array}{l}\text { Median } \\
38 \\
\text { (range } \\
14-66 \text { ) }\end{array}$ & $\begin{array}{c}\text { Inguinal (62), axillary (54), } \\
\text { genital (50), gluteal (41), } \\
\text { coccygeal (24), pectoral } \\
\text { (17) }\end{array}$ & $\begin{array}{l}\text { WLE with } \\
\text { secondary intention closure }\end{array}$ & $69 *$ \\
\hline $\begin{array}{l}\text { Humphries et al. }{ }^{26} \\
2016 \\
\text { United States }\end{array}$ & 17 & $\begin{array}{l}\text { Single centre, } \\
\text { retrospective }\end{array}$ & $\begin{array}{l}4 \text { men, } \\
13 \text { women }\end{array}$ & $\begin{array}{l}\text { Mean } \\
\text { for all } \\
\text { proced- } \\
\text { ures } \\
36.8 \\
\text { (range } \\
\text { 18-65) }\end{array}$ & $\begin{array}{l}\text { Axillary, breast, inguinal } \\
\text { area, perineum, mons } \\
\text { pubis/suprapubis, } \\
\text { presacrum, perianus, } \\
\text { abdomen, inner thighs, } \\
\text { gluteal }\end{array}$ & $\begin{array}{c}\text { WLE with } \\
\text { secondary intention closure } \\
\text { (including multiple excisions) }\end{array}$ & 11.8 \\
\hline $\begin{array}{l}\text { Blok et al. }{ }^{21} 2015 \\
\text { The Netherlands }\end{array}$ & 113 & Retrospective & $\begin{array}{c}36 \text { men }(31.9 \%) \text {, } \\
77 \text { women } \\
(68.1 \%)\end{array}$ & NA & $\begin{array}{l}\text { Axilla, inguinal, genital, } \\
\text { gluteal, other }\end{array}$ & Local excision and deroofing & 29.2 \\
\hline $\begin{array}{l}\text { Wormald et al. }{ }^{27} \\
2014 \\
\text { United Kingdom }\end{array}$ & 27 & $\begin{array}{l}\text { Retrospective, } \\
\text { questionnaires }\end{array}$ & $\begin{array}{c}8 \text { men }(30 \%) \\
19 \text { women } \\
(70 \%)\end{array}$ & $\begin{array}{l}\text { Mean } \\
34.7\end{array}$ & Axilla & $\begin{array}{l}\text { WLE } \\
\text { Graft, flaps }\end{array}$ & 3.7 \\
\hline $\begin{array}{l}\text { van Rappard et al. }{ }^{28} \\
2012 \\
\text { The Netherlands }\end{array}$ & 57 & $\begin{array}{l}\text { Retrospective, } \\
\text { questionnaires }\end{array}$ & $\begin{array}{c}10 \text { men }(18 \%) \text {, } \\
47 \text { women } \\
(82 \%)\end{array}$ & $\begin{array}{l}\text { Average } \\
42.5\end{array}$ & $\begin{array}{l}\text { Axilla, inguinal, genital, } \\
\text { perianal }\end{array}$ & $\begin{array}{l}\text { Local excision and primary } \\
\text { closure }\end{array}$ & 34 \\
\hline $\begin{array}{l}\text { Alharbi et al. }{ }^{29} \\
2012 \\
\text { Germany }\end{array}$ & 32 & Retrospective & $\begin{array}{c}12 \text { men }(37.5 \%) \text {, } \\
20 \text { women } \\
(62.5 \%)\end{array}$ & $\begin{array}{l}\text { Range } \\
17-51\end{array}$ & $\begin{array}{l}\text { Axilla, inguinal, perianal/ } \\
\text { perineal, gluteal, } \\
\text { inframammary }\end{array}$ & $\begin{array}{c}\text { WLE } \\
\text { Primary closure flap, graft }\end{array}$ & 16.75 \\
\hline $\begin{array}{l}\text { Büyükasik et al. }{ }^{30} \\
2011 \\
\text { Turkey }\end{array}$ & 15 & Retrospective & & $\begin{array}{l}\text { Mean } \\
\text { (SD } \\
10.6)\end{array}$ & $\begin{array}{c}\text { Groin, axilla, buttocks, } \\
\text { nuchae, perianal, perineal }\end{array}$ & $\begin{array}{c}\text { WLE } \\
\text { Primary closure, with } \\
\text { fasciocutaneous flaps and } \\
\text { with split-thickness skin grafts }\end{array}$ & 5.5 \\
\hline $\begin{array}{l}\text { van der Zee et al. }{ }^{23} \\
2010 \\
\text { The Netherlands }\end{array}$ & 44 & $\begin{array}{l}88 \text { deroofed } \\
\text { lesions }\end{array}$ & $\begin{array}{l}41 \text { women, } 3 \\
\text { men }\end{array}$ & $\begin{array}{l}\text { Median } \\
35 \\
\text { (range } \\
28-43 \text { ) }\end{array}$ & $\begin{array}{c}\text { Axillae (44.3), groin (46.6), } \\
\text { buttocks (9.1) }\end{array}$ & Deroofing technique & 17 \\
\hline $\begin{array}{l}\text { Civelek et al. }{ }^{31} \\
2010 \\
\text { Turkey }\end{array}$ & 14 & Retrospective & $\begin{array}{c}9 \text { women, } 5 \\
\text { men }\end{array}$ & $\begin{array}{l}\text { Not } \\
\text { provided }\end{array}$ & Axilla, inguinal & $\begin{array}{c}\text { WLE } \\
\text { Flap, graft }\end{array}$ & 29 \\
\hline $\begin{array}{l}\text { Menderes et al. }{ }^{32} \\
2010 \\
\text { Turkey }\end{array}$ & 27 & 54 sites & $\begin{array}{c}19 \text { men, }(70 \%) \\
8 \text { women }(30 \%) \text {, }\end{array}$ & $\begin{array}{c}41.2 \\
\text { (range } \\
24-58 \text { ) }\end{array}$ & $\begin{array}{c}\text { Axilla (42), gluteal (20), } \\
\text { perineal (24), inguinal (12) }\end{array}$ & $\begin{array}{c}\text { Primary closure flap, } \\
\text { graft }\end{array}$ & 7.5 \\
\hline $\begin{array}{l}\text { Rieger et al. }{ }^{33} 2009 \\
\text { Switzerland and } \\
\text { Austria }\end{array}$ & 8 & Retrospective & $\begin{array}{c}7 \text { women } \\
(87.5 \%) \\
1 \text { man }(12.5 \%)\end{array}$ & $\begin{array}{l}\text { Mean } 35 \\
\text { (range } \\
18-49)\end{array}$ & Inguinal & WLE, flap & 0 \\
\hline $\begin{array}{l}\text { Mandal et al. }{ }^{34} \\
2005 \\
\text { Scotland }\end{array}$ & 106 & & & $\begin{array}{l}\text { Median } \\
\text { at onset } \\
36 \\
\text { (range } \\
17-70 \text { ) }\end{array}$ & $\begin{array}{c}\text { Both axillae (36.2), } 1 \text { axilla } \\
\text { (21.6), axilla and groin (9.0), } \\
\text { groin only (14.6), perineum } \\
\text { (9.0), inframammary (5.5), } \\
\text { other (3.4) }\end{array}$ & $\begin{array}{c}\text { Primary closure (100 sites), } \\
\text { split skin graft (29 sites), flaps } \\
\text { (14 sites) }\end{array}$ & $70+$ \\
\hline $\begin{array}{l}\text { Kagan et al. }{ }^{35} 2005 \\
\text { United States }\end{array}$ & 57 & & $\begin{array}{c}15 \text { men }(26 \%) \text {, } \\
42 \text { women } \\
(74 \%)\end{array}$ & $\begin{array}{l}\text { Mean } 34 \\
\text { (range } \\
19-62 \text { ) }\end{array}$ & $\begin{array}{c}\text { Axilla (50), perineum (36), } \\
\text { inguinal (14) }\end{array}$ & $\begin{array}{c}\text { Local, wide, other } \\
\text { Primary, graft, secondary } \\
\text { wound healing } \\
\text { Excision and primary closure } \\
\text { for localized disease ( } 76 \% \text { of } \\
\text { axillary cases } \\
\text { WLE with or without STSG } \\
\text { with diffuse disease ( } 86 \% \text { of } \\
\text { inguinoperineal cases) }\end{array}$ & Not provided \\
\hline $\begin{array}{l}\text { Altmann et al. }{ }^{36} \\
2004 \\
\text { Germany }\end{array}$ & 20 & Retrospective & $\begin{array}{c}6 \text { men }(30 \%) \text {, } \\
14 \text { women } \\
(70 \%)\end{array}$ & $\begin{array}{l}\text { Average } \\
36 \\
\text { (range } \\
20-50)\end{array}$ & Axilla & WLE and flaps & 15 \\
\hline $\begin{array}{l}\text { Kuo and Ohara }{ }^{37} \\
2003 \\
\text { Japan }\end{array}$ & 6 & Retrospective & $\begin{array}{c}4 \text { men }(66 \%), \\
2 \text { women }(33 \%)\end{array}$ & $\begin{array}{l}\text { Average } \\
32.7\end{array}$ & Gluteal & WLE and grafts & 0 \\
\hline
\end{tabular}


Table 1 (part 2 of 2). Summary of articles on surgical interventions in patients with hydratenitis suppuritiva published since 2000

\begin{tabular}{|c|c|c|c|c|c|c|c|}
\hline Study and country & $\begin{array}{c}\text { No. of } \\
\text { patients }\end{array}$ & Study design & Sex & Age, yr & Location of surgery (\%) & Type(s) of procedure(s) & $\begin{array}{l}\text { Recurrence } \\
\text { rate, \% }\end{array}$ \\
\hline $\begin{array}{l}\text { Bocchini et al. }{ }^{38} \\
2003 \\
\text { Brazil }\end{array}$ & 56 & Retrospective & $\begin{array}{c}52 \text { men }(93 \%) \\
36 \text { women } \\
(64 \%)\end{array}$ & Mean 40 & $\begin{array}{c}\text { Gluteal, } \\
\text { perineal, inguinal }\end{array}$ & $\begin{array}{c}\text { WLE } \\
\text { Secondary intention healing, } \\
\text { delayed skin grafting } \neq\end{array}$ & 1.8 \\
\hline $\begin{array}{l}\text { Tanaka et al. }{ }^{39} \\
2001 \\
\text { Japan }\end{array}$ & 19 & Retrospective & & $\begin{array}{c}\text { Mean } \\
40.7 \\
\text { (range } \\
30-58 \text { ) }\end{array}$ & $\begin{array}{l}\text { Axillary, inguinal, gluteal } \\
\text { areas, other }\end{array}$ & $\begin{array}{c}\text { WLE } \\
\text { Primary flaps, graft }\end{array}$ & 43 \\
\hline $\begin{array}{l}\text { Bohn and } \\
\text { Svensson }{ }^{40} 2001 \\
\text { Sweden }\end{array}$ & 138 & $\begin{array}{l}\text { Retrospective, } \\
\text { questionnaires }\end{array}$ & & $\begin{array}{l}\text { Average } \\
23\end{array}$ & $\begin{array}{l}\text { Axilla, inguinal, perineal/ } \\
\text { perianal, inframammary, } \\
\text { other }\end{array}$ & $\begin{array}{c}\text { WLE } \\
\text { Primary graft }\end{array}$ & 33 \\
\hline $\begin{array}{l}\text { Soldin et al. }{ }^{19} 2000 \\
\text { South Africa }\end{array}$ & 59 & & $\begin{array}{l}42 \text { women, } \\
17 \text { men }\end{array}$ & $\begin{array}{c}\text { Average } \\
32 \\
\text { (range } \\
16-65)\end{array}$ & Axilla & $\begin{array}{l}\text { Local excision and WLE } \\
\text { Primary closure, flap, graft }\end{array}$ & $26.6 \S, 7.7 \emptyset$ \\
\hline $\begin{array}{l}\text { Rompel et al. }{ }^{41} \\
2000 \\
\text { Germany }\end{array}$ & 106 & & & & $\begin{array}{c}\text { Inguinal (70.8), axillary } \\
(61.3)\end{array}$ & WLE & 2.5 \\
\hline \multicolumn{8}{|c|}{$\begin{array}{l}\text { PMH = past medical history; SD = standard deviation; STSG = split-thickness skin grafting; WLE= } \\
\text { *Reported by patients via questionnaires. } \\
\text { IIn the primary closure series. } \\
\text { fSecondary intention healing in } 32 \text { patients }(57.1 \%) \text {; delayed skin grafting in } 24 \text { patients }(42.9 \%) \text {. } \\
\text { §Local excision. } \\
\text { q Excision of all hair-bearing skin. }\end{array}$} \\
\hline
\end{tabular}

after healing, simplified the surgical procedure and is supported by other studies in the literature. ${ }^{13,24-26}$ The disadvantage of secondary intention healing is the dressing care required until the wound is closed. This was well tolerated in our patients, who are generally used to dressing care for their active disease. The patients who underwent primary closure experienced dehiscence of more than $30 \%$ (minor and major dehiscence) even though they were being maintained on their preoperative medical treatments.

All patients in this series were followed by a dermatologist and had their medical therapy continued in the perioperative and postoperative periods. Seventy-seven percent of patients were on biologic therapies, and these were not discontinued or withheld perioperatively. In this series we were not able to show a difference in outcome for the patients on biologics; however, we emphasize the necessity of continuation of such treatment throughout the management of patients with HS.

\section{Limitations}

Our study has some limitations, including patient selection and retrospective design, and therefore the risk of bias. Also, our study is limited by its relatively small sample size.

\section{Conclusion}

Wide local excision to healthy subcutaneous adipose tissue provides good control of HS. The $18 \%$ local recurrence rate reported here is at the better end of the rates reported in other series in the literature. Wide local excision with secondary intention closure is a useful and practical surgical approach, which is facilitated by not resecting to fascia. It can simplify the surgical procedure while providing equivalent local control and extremity function. Primary closure in HS is associated with a significant dehiscence rate of which surgeons and patients should be aware. Larger studies with a better design and longer follow-up are required to determine the optimal surgical approach and optimal medical control.

Affiliation: From the Department of Medicine, Women's College Hospital, and the Department of Surgery, CIBC Breast Centre, St. Michael's Hospital, University of Toronto, Toronto, Ont.

Competing interests: None declared.

Contributors: E. Shavit, A. Alavi and R. George designed the study. All authors acquired the data, which E. Shavit, A. Alavi and R. George analyzed. E. Shavit and R. George wrote the article, which all authors reviewed and approved for publication.

\section{References}

1. Jemec GB. Clinical practice. Hidradenitis suppurativa. $N$ Engl 7 Med 2012;366:158-64.

2. Hurley H. Axillary hyperhisrosis apocrine bromohidrosis, hidradenitis suppurativa, and familial benign pemphigus; surgical approach. In: Roenigh R, Roenigh H, editors. Dermatologic surgery. New York: Marcel Dekker; 1989:729-39.

3. Sartorius K, Emtestam L, Jemec GB, et al. Objective scoring of hidradenitis suppurativa reflecting the role of tobacco smoking and obesity. Br 7 Dermatol 2009;161:831-9.

4. Kimball AB, Jemec GB, Yang M, et al. Assessing the validity, responsiveness and meaningfulness of the hidradenitis suppurativa clinical response (HiSCR) as the clinical endpoint for hidradenitis suppurativa treatment. Br 7 Dermatol 2014;171:1434-42.

5. Alikhan A, Lynch PJ, Eisen DB. Hidradenitis suppurativa: a comprehensive review. 7 Am Acad Dermatol 2009;60:539-61. 
6. van Straalen KR, Schneider-Burrus S, Prens EP. Current and future treatment of hidradenitis suppurativa. Br 7 Dermatol 2018;10.1111/ bjd. 16768 .

7. Alavi A, Lynde C, Alhusayen R, et al. Approach to the management of patients with hidradenitis suppurativa: a consensus document. 7 Cutan Med Surg 2017;21:513-24.

8. Pink A, Anzengruber F, Navarini AA. Acne and hidradenitis suppurativa. Br 7 Dermatol 2018;178:619-31.

9. Mehdizadeh A, Hazen PG, Bechara FG, et al. Recurrence of hidradenitis suppurativa after surgical management: a systematic review and meta-analysis. 7 Am Acad Dermatol 2015;73(Suppl 1):S70-7.

10. Posch C, Monshi B, Quint T, et al. The role of wide local excision for the treatment of severe hidradenitis suppurativa (Hurley grade III): retrospective analysis of 74 patients. 7 Am Acad Dermatol 2017;77:123-129.e5.

11. Mitchell KM, Beck DE. Hidradenitis suppurativa. Surg Clin North Am 2002;82:1187-97.

12. Ritz JP, Runkel N, Haier J, et al. Extent of surgery and recurrence rate of hidradenitis suppurativa. Int 7 Colorectal Dis 1998;13:164-8.

13. Deckers IE, Dahi Y, van der Zee HH, et al. Hidradenitis suppurativa treated with wide excision and second intention healing: a meaningful local cure rate after 253 procedures. 7 Eur Acad Dermatol Venereol 2018;32:459-62.

14. Hazen PG, Hazen BP. Hidradenitis suppurativa: successful treatment using carbon dioxide laser excision and marsupialization. Dermatol Surg 2010;36:208-13.

15. Levoska MA, Nicholson CL, Hamzavi IH. A retrospective review of light- and laser-based management of hidradenitis suppurativa. Semin Cutan Med Surg 2017;36:67-74.

16. Abdel Azim AA, Salem RT, Abdelghani R. Combined fractional carbon dioxide laser and long-pulsed neodymium: yttrium-aluminiumgarnet $(1064 \mathrm{~nm})$ laser in treatment of hidradenitis suppurativa; a prospective randomized intra-individual controlled study. Int $\mathcal{F}$ Dermatol 2018;57:1135-44.

17. Schneider-Burrus S, Jost A, Peters EMJ, et al. Association of hidradenitis suppurativa with body image. 7AMA Dermatol 2018;154:447-51.

18. Ring HC, Bay L, Nilsson M, et al. Bacterial biofilm in chronic lesions of hidradenitis suppurativa. Br 7 Dermatol 2017;176:993-1000.

19. Soldin MG, Tulley P, Kaplan H, et al. Chronic axillary hidradenitis - the efficacy of wide excision and flap coverage. $\mathrm{Br} \mathcal{F}$ Plast Surg 2000;53:434-6.

20. Danby FW, Hazen PG, Boer J. New and traditional surgical approaches to hidradenitis suppurativa. 7 Am Acad Dermatol 2015;73(Suppl 1):S62-5.

21. Blok JL, Boersma M, Terra JB, et al. Surgery under general anesthesia in severe hidradenitis suppurativa: a study of 363 primary operations in 113 patients. 7 Eur Acad Dermatol Venereol 2015;29:1590-7.

22. Walter AC, Meissner M, Kaufmann R, et al. Hidradenitis suppurativa after radical surgery-long-term follow-up for recurrences and associated factors. Dermatol Surg 2018;44:1323-31.

23. Van der Zee HH, Prens EP, Boer J. Deroofing: a tissue-saving surgical technique for the treatment of mild to moderate hidradenitis suppurativa lesions. 7 Am Acad Dermatol 2010;63:475-80.
24. Bieniek A, Matusiak Ł, Chlebicka I, et al. Secondary intention healing in skin surgery: our own experience and expanded indications in hidradenitis suppurativa, rhinophyma and non-melanoma skin cancers. 7 Eur Acad Dermatol Venereol 2013;27:1015-21.

25. Kofler L, Schweinzer K, Heister M, et al. Surgical treatment of hidradenitis suppurativa: an analysis of postoperative outcome, cosmeticresults and quality of life in 255 patients. 7 Eur Acad Dermatol Venereol 2018;32:1570-74.

26. Humphries LS, Kueberuwa E, Beederman M, et al. Wide excision and healing by secondary intent for the surgical treatment of hidradenitis suppurativa: a single-center experience. 7 Plast Reconstr Aesthet Surg 2016;69:554-66.

27. Wormald JC, Balzano A, Clibbon JJ, et al. Surgical treatment of severe hidradenitis suppurativa of the axilla: thoracodorsal arteryperforator (TDAP) flap versus split skin graft. 7 Plast Reconstr Aesthet Surg 2014;67:1118-24.

28. van Rappard DC, Mooij JE, Mekkes JR. Mild to moderate hidradenitis suppurativa treated with local excision and primary closure. 7 Eur Acad Dermatol Venereol 2012;26:898-902.

29. Alharbi Z, Kauczok J, Pallua N. A review of wide surgical excision of hidradenitis suppurativa. BMC Dermatol 2012;12:9.

30. Büyükasik O, Hasdemir AO, Kahramansoy N, et al. Surgical approach to extensive hidradenitis suppurativa. Dermatol Surg 2011;37:835-42.

31. Civelek B, Aksoy K, Bileen E, et al. Reconstructive options in severe cases of hidradenitis suppurativa. Cent Eur F Med 2010;5:674-8.

32. Menderes A, Sunay O, Vayvada H, et al. Surgical management of hidradenitis suppurativa. Int 7 Med Sci 2010;7:240-7.

33. Rieger UM, Erba P, Pierer G, et al. Hidradenitis suppurativa of the groin treated by radical excision and defect closure by medialthigh lift: aesthetic surgery meets reconstructive surgery. $\mathcal{F}$ Plast Reconstr Aesthet Surg 2009;62:1355-60.

34. Mandal A, Watson J. Experience with different treatment modules in hidradenitis suppurativa: a study of 106 cases. Surgeon 2005;3:23-6.

35. Kagan RJ, Yakuboff KP, Warner P, et al. Surgical treatment of hidradenitis suppurativa: a 10-year experience. Surgery 2005;138:73440, discussion 740-1.

36. Altmann S, Fansa H, Schneider W. Axillary hidradenitis suppurativa: a further option for surgical treatment. 7 Cutan Med Surg 2004; 8:6-10.

37. Kuo HW, Ohara K. Surgical treatment of chronic gluteal hidradenitis suppurativa: reused skin graft technique. Dermatol Surg 2003; 29:173-8.

38. Bocchini SF, Haber-Gama A, Kiss DR, et al. Gluteal and peripheral hidradenitis suppurativa: surgical treatment by wide excision. Dis Colon Rectum 2003;46:944-9.

39. Tanaka A, Hatoko M, Tada H, et al. Experience with surgical treatment of hidradenitis suppurativa. Ann Plast Surg 2001;47:636-42.

40. Bohn J, Svensson H. Surgical treatment of hidradenitis suppurativa. Scand 7 Plast Reconstr Surg Hand Surg 2001;35:305-9.

41. Rompel R, Petres J. Long-term results of wide surgical excision in 106 patients with hidradenitis suppurativa. Dermatol Surg 2000;26:638-43. 